Jurnal ASPIKOM, Vol. 7, No. 1, January 2022, pp. 173-189

P-ISSN: 2087-0442, E-ISSN: 2548-8309

DOI: http://dx.doi.org/10.24329/aspikom.v7i1.1067

\title{
Digital Literacy Competence Survey in Medan City
}

\author{
Yovita Sabarina Sitepu*, Mickhael Rajagukguk \\ Universitas Sumatera Utara, Jalan Dr. A. Sofian No.1A, Medan, Indonesia \\ *Corresponding author, e-mail: yovita.sabarina@usu.ac.id
}

\begin{abstract}
This study measures Medan's level of digital literacy competence. This study aims to obtain an overview of the digital literacy competencies of smartphone users in Medan City. This research was part of the National Digital Literacy Research, initiated by the Network of Digital Literacy Activists (Japelidi), conducted in 18 cities in Indonesia, involving 125 respondents from Medan City, and divided into five age segments. The research used the descriptive quantitative method. As the instrument, the research used ten Components of Japelidi's Digital Literacy, which are the ability to access, select, understand, analyze, verify, evaluate, distribute, produce, participate, and collaborate. Digital literacy competence in Medan City showed an imbalance between the younger generation and the elderly. This inequality is not only based on age differences alone but also differences in culture and use of technology in each era.
\end{abstract}

Keywords: Digital literacy; Generation; Japelidi; Medan city

\begin{abstract}
Abstrak
Penelitian ini mengukur tingkat kompetensi literasi digital masyarakat Kota Medan. Tujuan dari penelitian ini adalah mendapatkan gambaran kompetensi literasi digital masyarakat pengguna gawai dengan akses internet di Kota Medan. Penelitian ini merupakan bagian dari Riset Nasional Literasi Digital Jaringan Pegiat Literasi Digital (Japelidi), yang dilakukan di 18 kota di Indonesia, dengan melibatkan 125 responden untuk wilayah Kota Medan, dan terbagi ke dalam 5 segmentasi usia yang berbeda. Metode penelitian yang digunakan dalam penelitian ini adalah deskriptif kuantitatif. Instrumen penelitian menggunakan 10 Komponen Literasi Digital Japelidi, yang terdiri dari kemampuan mengakses, menyeleksi, memahami, menganalisis, memverifikasi, mengevaluasi, mendistribusikan, memproduksi, berpartisipasi, dan berkolaborasi. Kompetensi literasi digital di Kota Medan menunjukkan terdapat ketimpangan antara kelompok usia generasi muda dengan usia lanjut. Ketimpangan tersebut tidak hanya didasarkan kepada perbedaan usia semata, melainkan adanya perbedaan kultur dan pemanfaatan teknologi pada masing-masing zaman.
\end{abstract}

Kata Kunci: Literasi Digital; Generasi; Japelidi; Kota Medan 


\section{Introduction}

The development of internet technology impacts the number of internet and social media users in Indonesia (Kholisoh, 2018). Internet development, through digital media, has become an inseparable part of daily life today (Herlina, 2019). In addition, the convergence of media on online media platforms also provides an opportunity for viewers to enjoy entertainment content anywhere and anytime (Pradsmadji \& Irwansyah, 2020)

North Sumatra is one of the provinces with a rapid increase in internet users. Telecommunication Statistics in Indonesia 2018 noted that internet users in North Sumatra had a penetration of $34.27 \%$ of the total population. This figure increased from 2014, which was only 14.4\% (BPS-Statistics Indonesia, 2019b, p. 125)

The Indonesian Internet Service Provider Association (APJII) in 2018 also noted that North Sumatra occupies the top position as the most internet user on Sumatra Island, with a user contribution of $6.3 \%$ in Indonesia. When calculated with the total population of North Sumatra Province, the number of internet users in North Sumatra is 10.5 million people, or equivalent to $75.3 \%$ of the North Sumatra population (Ariyanti, 2019).

Internet users in North Sumatra classified as high are still not balanced with safety in obtaining factual information. The General Election Supervisory Agency (Bawaslu) noted that North Sumatra is a row of 12 provinces with a category prone to spreading false news or hoaxes during the 2018 Regional Head Election (Pilkada) (Antara, 2018). (DailySocial.id, 2018) found that $53.25 \%$ of Indonesian people always receive fake news every day, whereas Facebook, WhatsApp, and Instagram are the top three social media for spreading hoaxes.

Today, much information presented on digital media can be obtained in just minutes from various directions (Loisa et al., 2019). The impact of digitalization makes it easier for people to get information, ranging from positive ones to those that can give anxiety to the public (Widiastuti \& Ritonga, 2020). The number of available sources of information and the high dependence of society on media consumption is very vulnerable to receiving hoax issues (Rosemary et al., 2021). In addition, the motive for seeking and sharing information by the audience customized to the needs, values, and ideological orientation, often makes the majority of the audience uncritical of the sources of reference information (Rianto, 2016).

The character of new media that facilitates the dissemination of information absolutely can be fertile ground for the deployment of false information or hoaxes (Nurlatifah, 2019). The fabrication information more and more spread along with the increasing frequency of internet consumption (Kurnia \& Astuti, 2017; Sulthan \& Istiyanto, 2019).

The concept of receiving information in each age group is another obstacle, considering that each generation has a different social perspective in responding to a piece of information (Susilo et al., 2020). It is also closely related to the level of digital literacy that is relatively low and is one form of the digital divide experienced by society (Hasfi et al., 2020).

This phenomenon ultimately requires internet users to verify before receiving information (Haryanto, 2014, p. 172). First, available information must be processed with the cognitive abilities that underlie one's attitudes and behavior to avoid exposure to hoaxes (Mansur et al., 2021). It is the principal pillar of why digital literacy needs to be advanced to become an opportunity and strength for the nation (Musiin \& Indrajit, 
2020).

Good digital literacy skills are not only seen from their ability to operate tools but can take advantage of digital media (Kusumastuti et al., 2021). Digital skills as part of digital literacy need to be sharpened constantly, so that crime and self-harm do not occur (Monggilo et al., 2021). Digital literacy is considered very important because it is a form of continuing education to the community (Suryatmoko \& Saputro, 2015).

Research conducted by Japelidi focuses on measuring digital literacy using the 10 Components of Japelidi's Digital Literacy. Respondents involved in the national scale as many as 2,280 respondents, of which 125 respondents came from Medan City. A similar study was conducted in Finland by (Khan \& Vuopala, 2019), with the research title Digital Competence Assessment Across Generations: A Finnish Sample Using the Digcomp Framework. This quantitative study involved 197 respondents from 4 different generational groups in Finland using the DigComp framework.

The research in Medan conducted by Japelidi is still relatively new. The determination of respondents by Japelidi tends to be larger than several studies, such as the Indonesian Digital Literacy Status Survey conducted by the Ministry of Communications and Information Technology with the Katadata Insight Center (KIC). They used a sample of 1670 respondents throughout Indonesia, involving 60 respondents in the Province of North Sumatra (Kementerian Komunikasi dan Informatika \& Katadata Insight Center, 2020). Meanwhile, the total number of respondents involved in Japelidi's national research was 125 respondents with a specific focus on measurement at the Medan City level.

The determination of the sample per regency/city of 125 respondents is considered more numerous and more specific at the city level. However, it is undeniable that this research still faces many obstacles, ranging from cost to time. This digital literacy data in Medan City is expected to be the basis and reference for research that discusses further digital literacy, both at local and national levels.

\section{Method}

The descriptive quantitative method is used in this research by using a questionnaire to collect data. Descriptive research design uses independent variables or only one variable (Sugiyono \& Susanto, 2017, p. 165). So, in quantitative descriptive research, researchers do not make comparisons of variables or look for relationships between these variables and other variables (Sugiyono, 2019, p. 64). The selected respondents had a device with internet access and were divided into five age segments, namely 13-16 years, 17-20 years, 21-36 years, 37-55 years, and over 55 years old. This research was descriptive with data presentation using data analysis in the form of frequency distribution and cross-tabulation.

This research was part of the National Digital Literacy Research, initiated by the Network of Digital Literacy Activists (Japelidi) using a survey method. A survey research method is a quantitative research method used to obtain data that has occurred in the past or present about beliefs or opinions from samples taken from specific populations, whose research results tend to be generalized (Sugiyono, 2019, p. 57). This research cooperated with 45 universities and 18 cities in Indonesia, with 125 respondents in each city. This survey was conducted in each region from August 2, 2019, to October 30, 2019, with 2,280 respondents.

The research instrument used ten Components of Japelidi's Digital Literacy adapted from the new media literacy framework by Lin et al. (2013). The ten 
components that serve as the framework for thinking are Consuming Skill, Understanding, Analysis, Synthesis, Evaluation, Presuming Skill, Distribution, Production, Participation, and Creation. Japelidi then replaced two competencies, namely production and creation skills, into selecting and collaborating, as a form of aligning digital literacy competencies according to the context of Indonesian society. So, the research instrument used ten Components of Japelidi's Digital Literacy, which are the ability to access, select, understand, analyze, verify, evaluate, distribute, produce, participate, and collaborate (Kurnia et al., 2018). The instrument consists of 46 questions with answer choices in the form of a Likert scale.

\section{Results and Discussion}

This study specifically addresses the 46 questions listed in the questionnaire, consisting of 16 questions regarding the demographics of the respondents and 30 questions on operational variables. Each question on the operational variables is a derivative of the 10 Components of Japelidi's Digital Literacy. The results are then tabulated based on the age group of research respondents in Medan City, with a score range of 1-5 for each competency (1=Very Low, $2=$ Low, $3=$ Sufficient, 4= High, and $5=$ Very High) (Gelgel et al., 2021).

\section{Gender Distribution of Respondents}

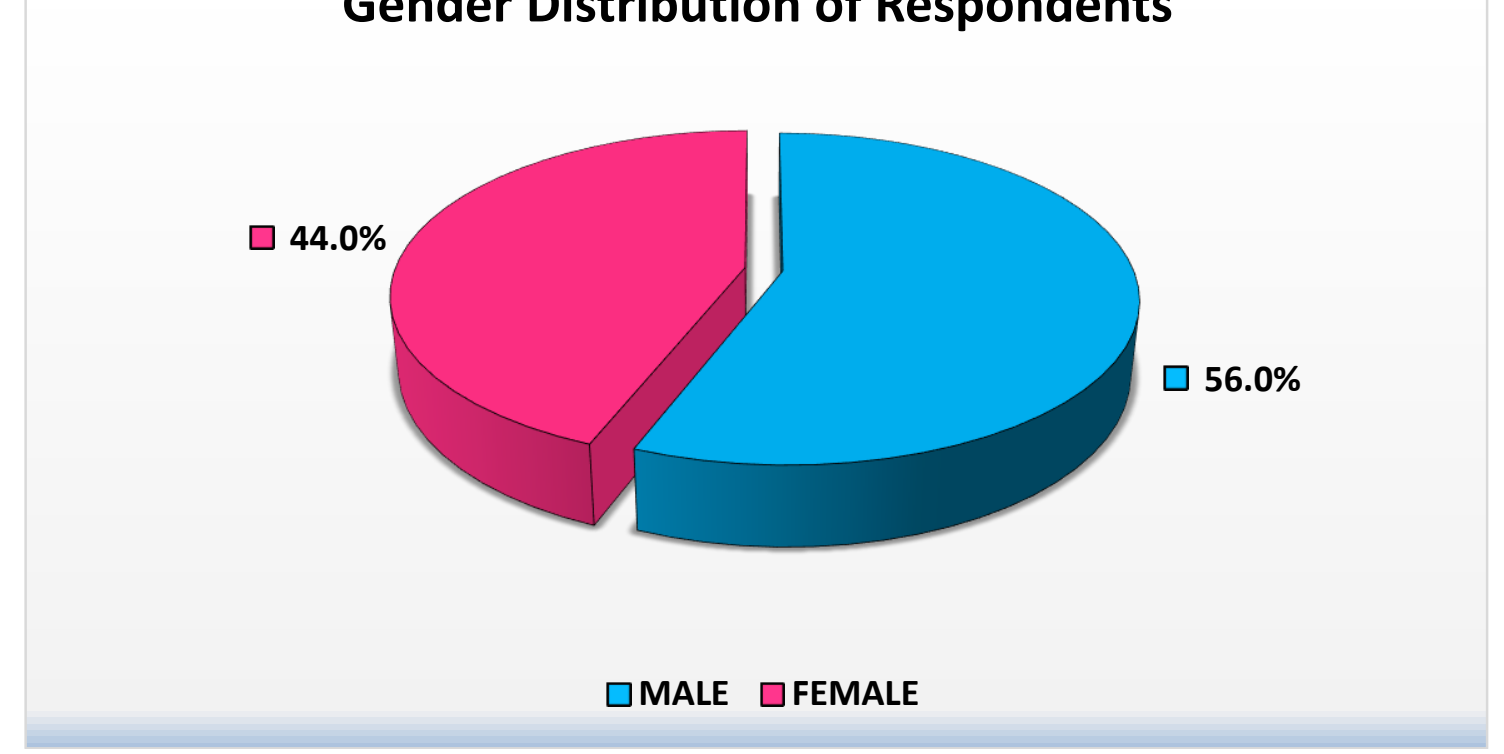

Figure 1. Respondent's Gender

This study involved 55 women (44\%) and 70 male respondents (56\%). It is in line with a survey conducted by the (BPS-Statistics Indonesia, 2019a, p. 25) through Statistics of Socio Culture 2018, which found that the male gender was the most internet access users in Indonesia. 


\section{Age Distribution of Respondents}

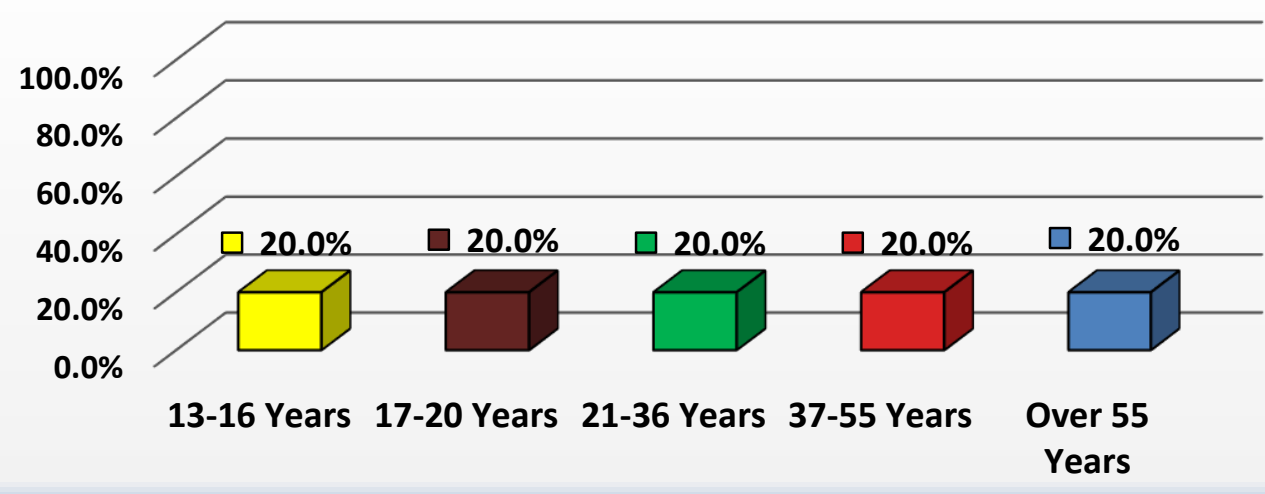

Figure 2. Respondent's Age

Respondents involved in this study were 125 people divided equally for each age group. The following diagram illustrates the distribution of the number of respondents for each age group, where each age group consists of 25 respondents or $20 \%$ of the total respondents. This age division is designed to be balanced between groups to find how the comparison of digital literacy skills will be clear later.

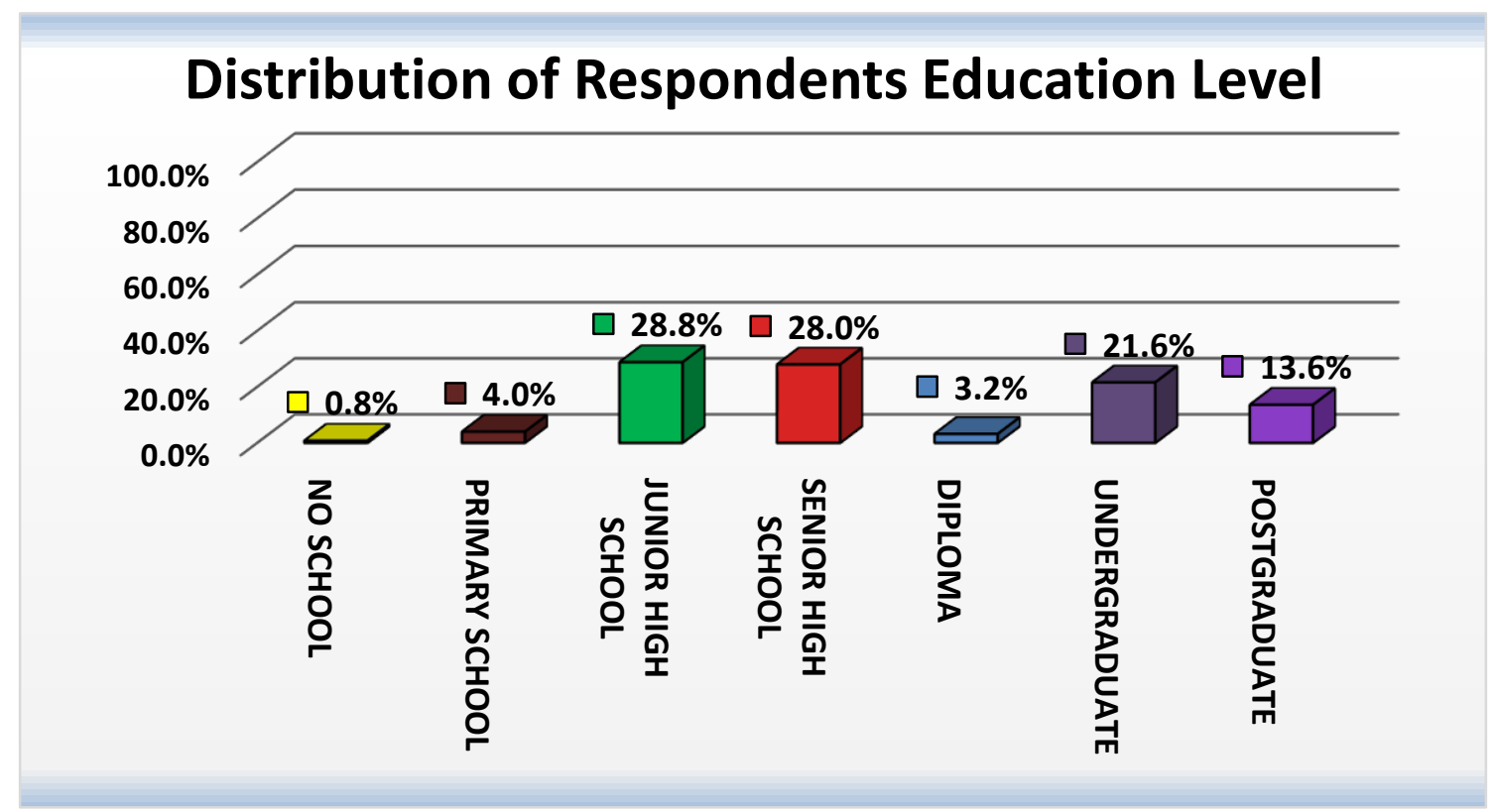

Figure 3. Respondent's Education Level

Figure 3 is the distribution of the education level of the respondents who participated in this study. The majority of the selected respondents had their last education at the junior high school level with a percentage of $28.8 \%$. Furthermore, $28 \%$ of the respondents were at the high school level, then $21.6 \%$ were respondents with the last education at the undergraduate level. The distribution of other respondents' education levels can be seen in the figure above. 


\section{Daily Internet Access Time}

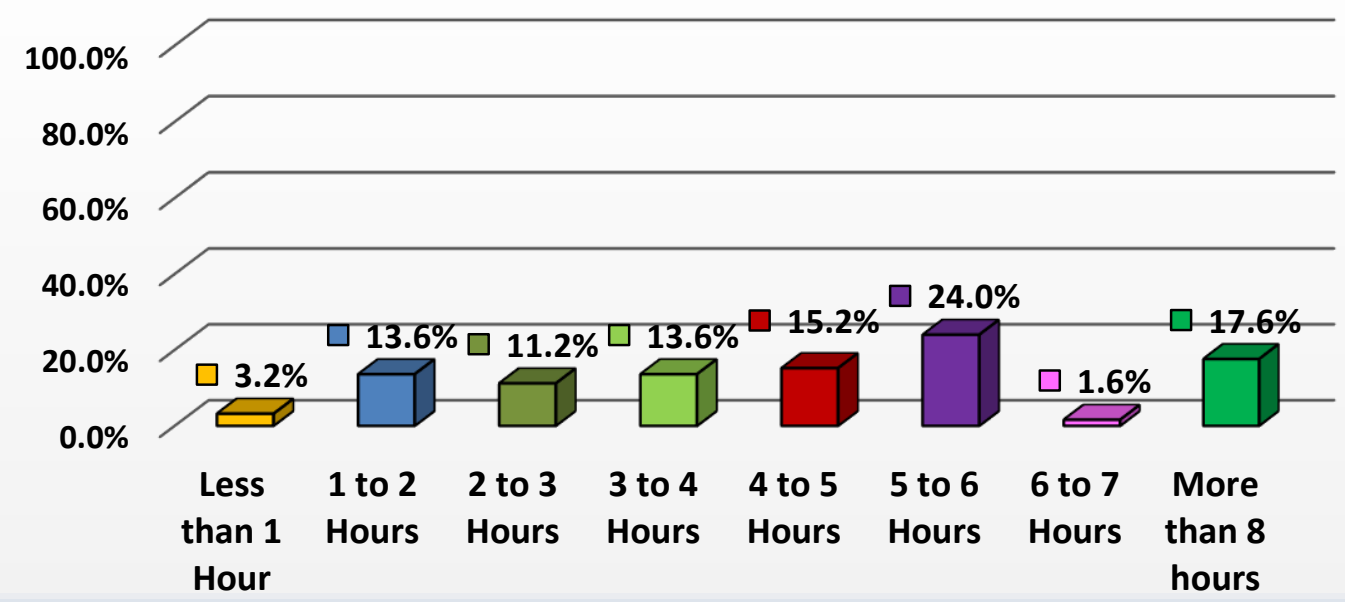

Figure 4. Daily Internet Access Time

When referring to the duration of internet access set by the Alvara Research Center, there are four categories of internet usage duration: light users (less than 1 hour), Medium Users (1-3 hours), Heavy Users (4-6 hours), Addicted Users (7-10 hours and more than 10 hours) (Hasanuddin, 2021). The findings in the research in Medan City show that the majority of people in Medan City are classified as heavy users that is $40.8 \%$, followed by medium users at $38.4 \%$, addicted users at $17.6 \%$, and light users at 3.2. $\%$.

\section{Distribution of Applications Used by Respondents}

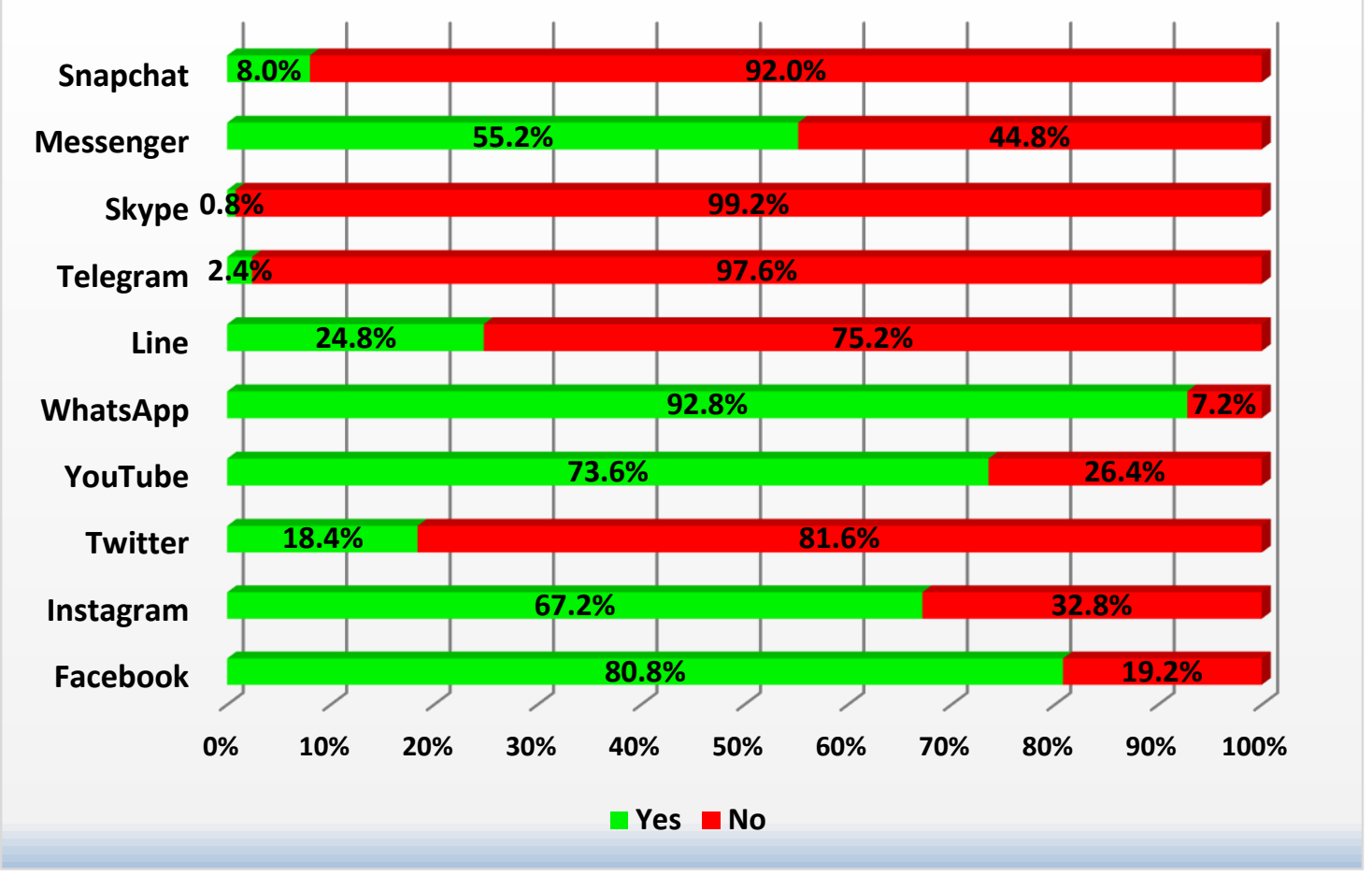

Figure 5. Applications Used by Respondents 
WhatsApp is the most used social media that is $92.8 \%$ of the total respondents in this study. Next, social media Facebook and Youtube have $80.8 \%$ and $73.6 \%$ of total respondents, respectively. Furthermore, other social media used by respondents can see from the bar graph below. These results are very different from the findings obtained by several survey institutions that claim YouTube and Facebook as the social media with the most active users in Indonesia. We are Social \& Hootsuite (2019) states that $88 \%$ of Indonesians use YouTube and The Indonesian Internet Service Providers Association (2018) places Facebook as the most widely used social media in Indonesia, with a percentage of $50.7 \%$.

The findings in Medan City show a trend of $92.8 \%$ of the people of Medan City to prefer the messaging application, namely WhatsApp, compared to watching videos via YouTube or updating status via Facebook. It also emphasized that the WhatsApp application as a social media is the most widely used, proof that the people of Medan City need communication support applications as human characters in general as social beings.

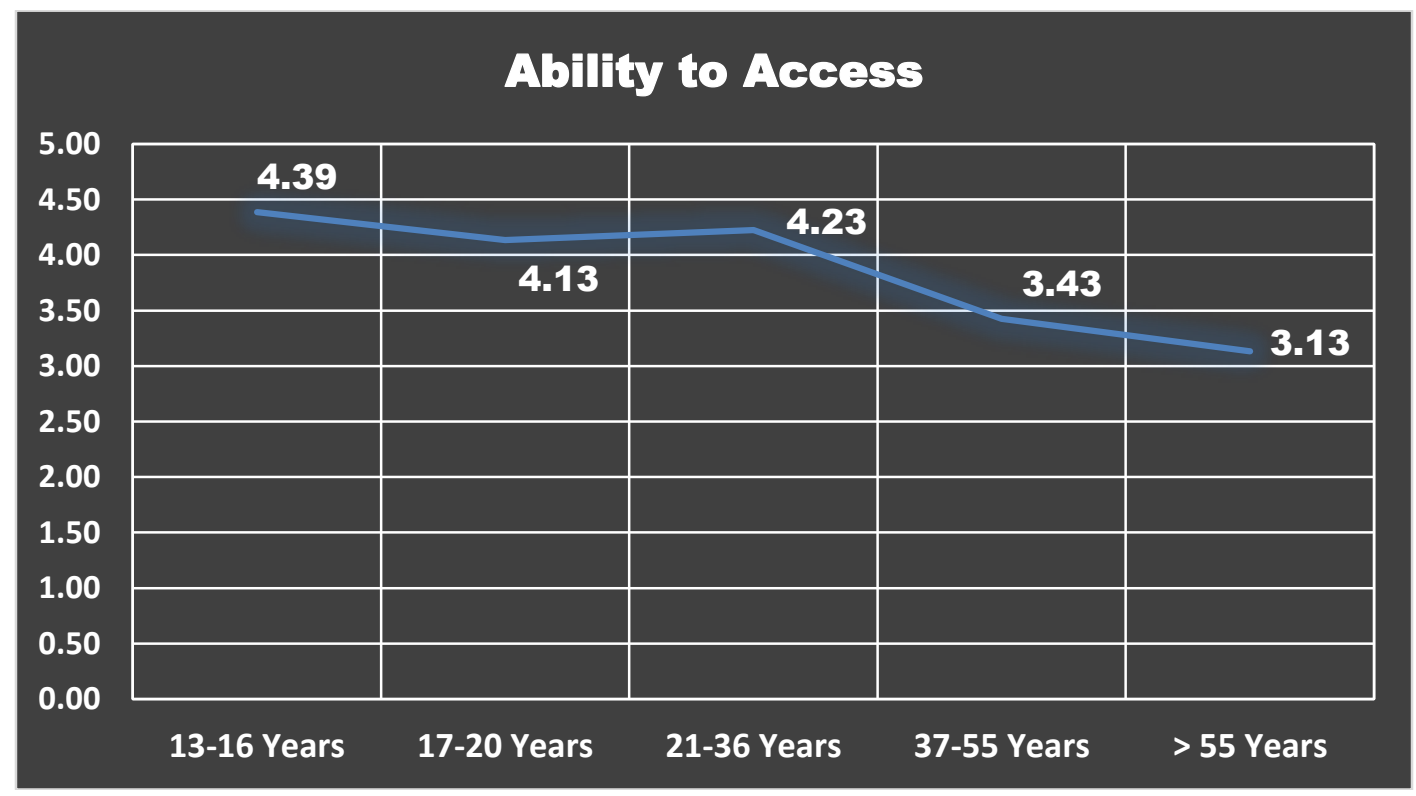

Figure 6. Ability to Access

The age groups of 13-16, 17-20, and 21-36 have high access ability. Meanwhile, those aged 37-55 and above 55 have the competence in the sufficient category. Practical forms of access ability in this study include using digital devices to access the internet, search engines, and various information on the internet through applications.

This ability is one of the primary abilities in the face of increasingly developing technological modernization. When looking at the results of digital literacy in accessing the city of Medan, researchers believe that these above-average abilities can help every level of society to adapt to digitalization. 


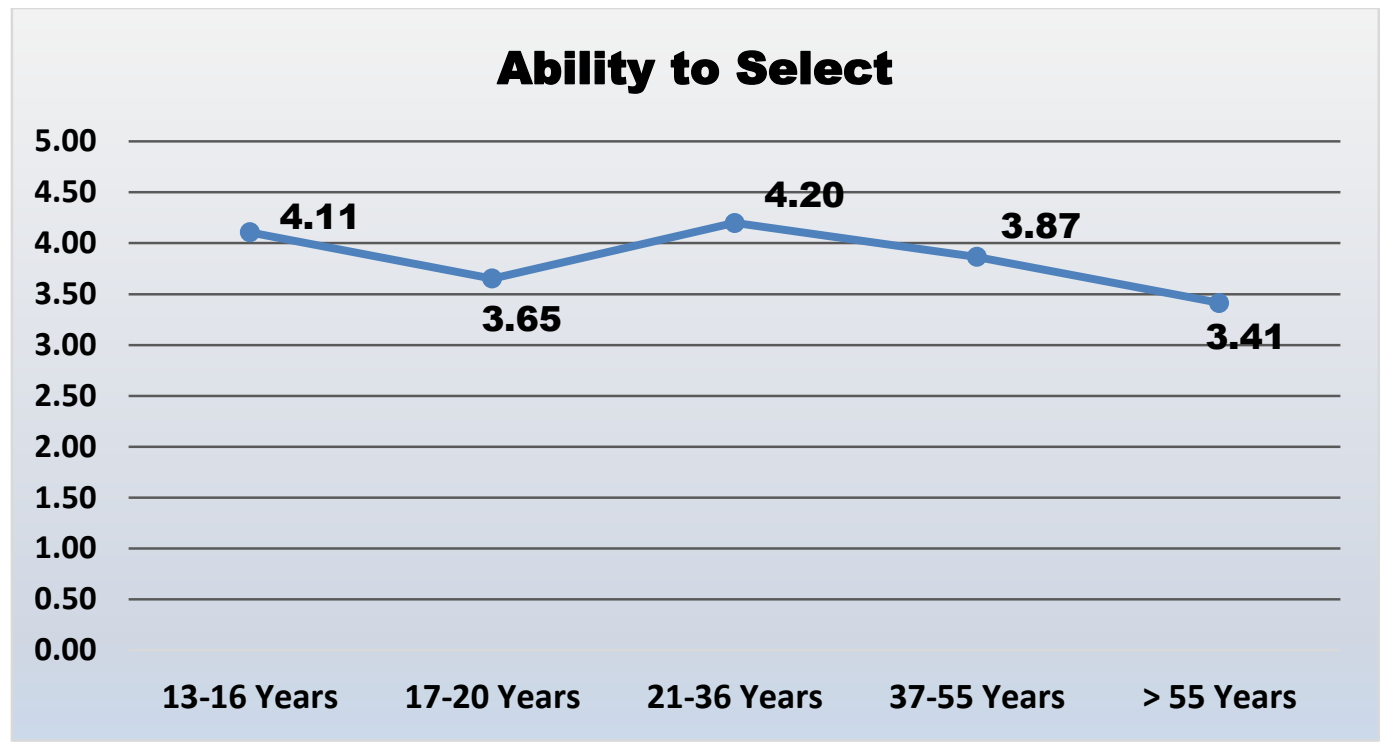

Figure 7. Ability to Select

The ability to select becomes the next skill in digital literacy, where the age group of 13-16 years and 21-36 years has a relatively high level of competence. Meanwhile, the age group of 17-20 years, 37-55 years, and above 55 years are in the good category. The ability to select here wants to see how people can choose information according to their needs, to ignore and delete any information considered deviant by them.

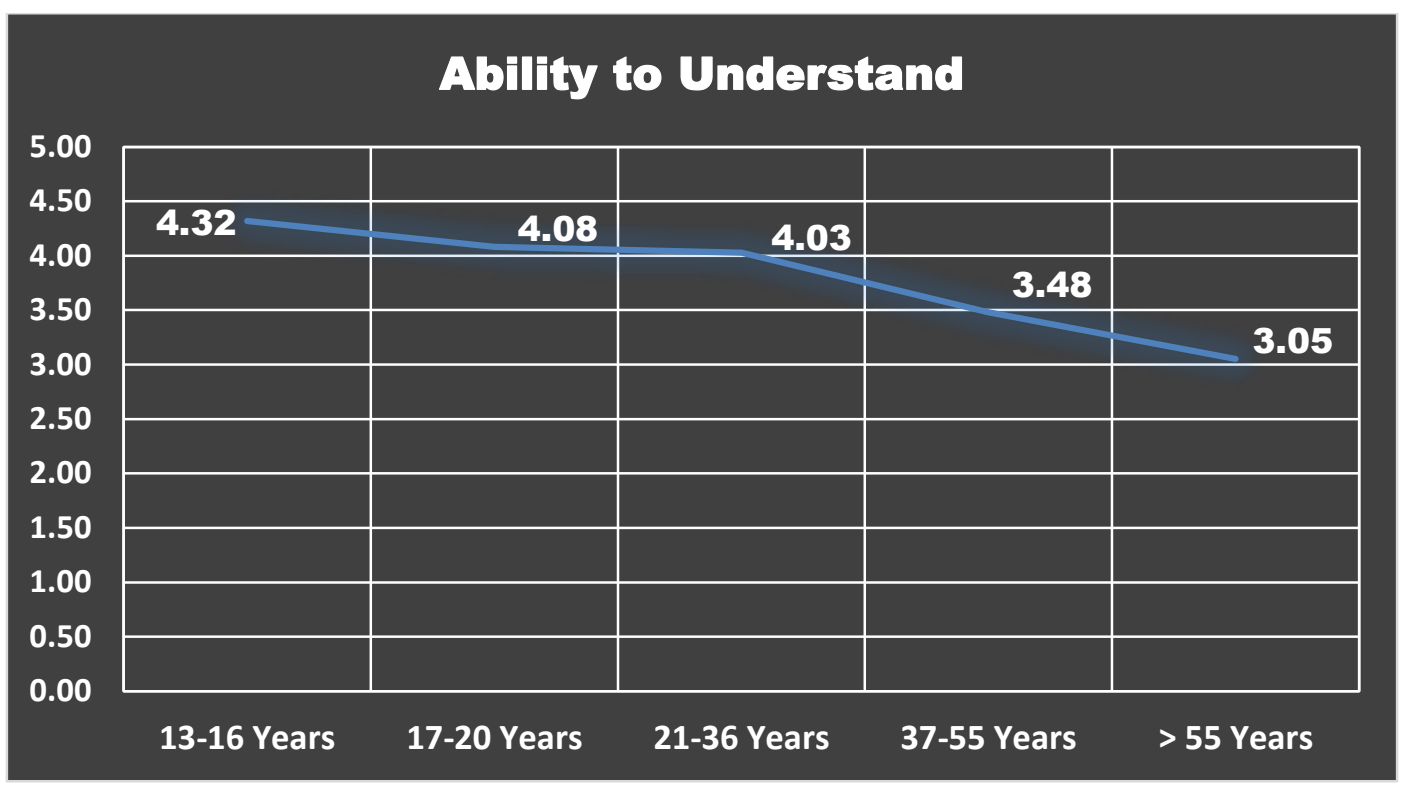

Figure 8. Ability to Understand

The ability to understand as a component of digital literacy found that the age groups of 13-16 years, 17-20 years, and 21-36 years were at a high level. Meanwhile, the age group of 37-55 years and above 55 years have a value with sufficient category in the ability to understand. The ability to understand is a form of digital activity, in understanding information both in the form of language, symbols, and audiovisual.

The ability to understand is one of the necessary indicators, given the variety of meanings contained in a message conveyed. Thus, capturing and understanding digital media users is needed to avoid misunderstandings when they receive information. 


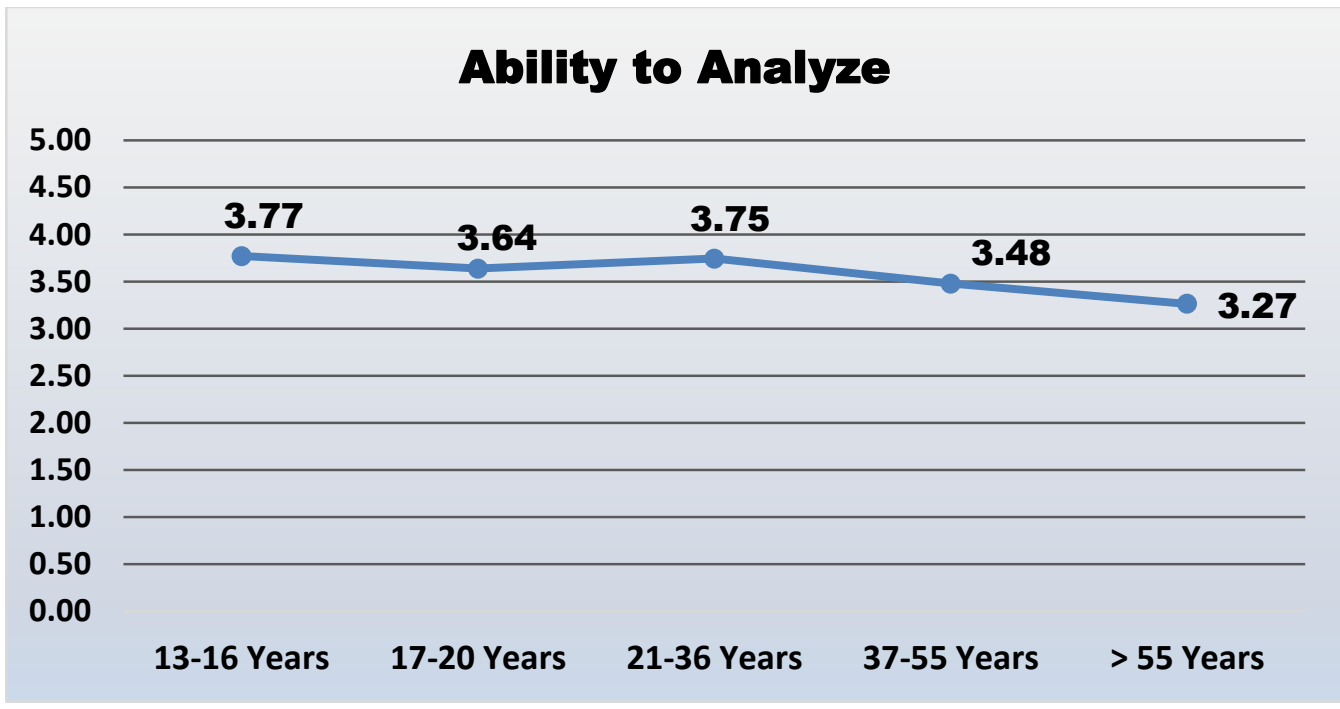

Figure 9. Ability to Analyze

In the ability to analyze, the findings of all age groups in Medan City were in the sufficient category. The ability to analyze refers to digital literacy is to see how digital media users can understand the meaning of information based on its format. In addition, this competence also measures how they relate information to the purpose of the message maker as well as identify the diversity of meanings in the information. This ability is a form of comprehension ability can explore the message received in detail. So that the recipient of the information can decide on the received information, whether it is true or false, accepted or deleted.

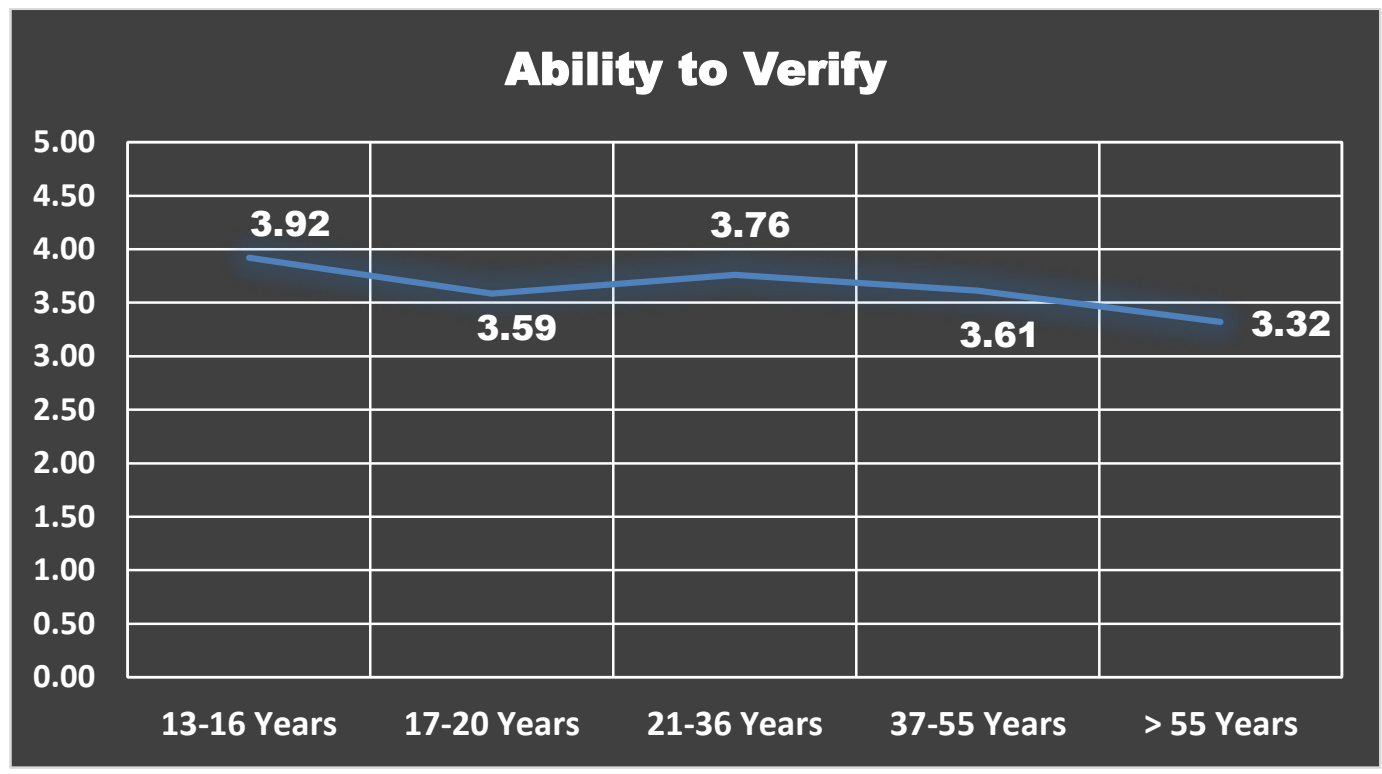

Figure 10. Ability to Verify

The ability to verify in Medan City overall is at a sufficient level if seen from the survey results. When referring to the daily use of digital media, this ability will help digital devices users to avoid fake news. Verification capabilities specifically look at how digital device users can compare information from various received sources. Not only that, but the verification capability also requires users can identify errors and determine the truth of any information received. 


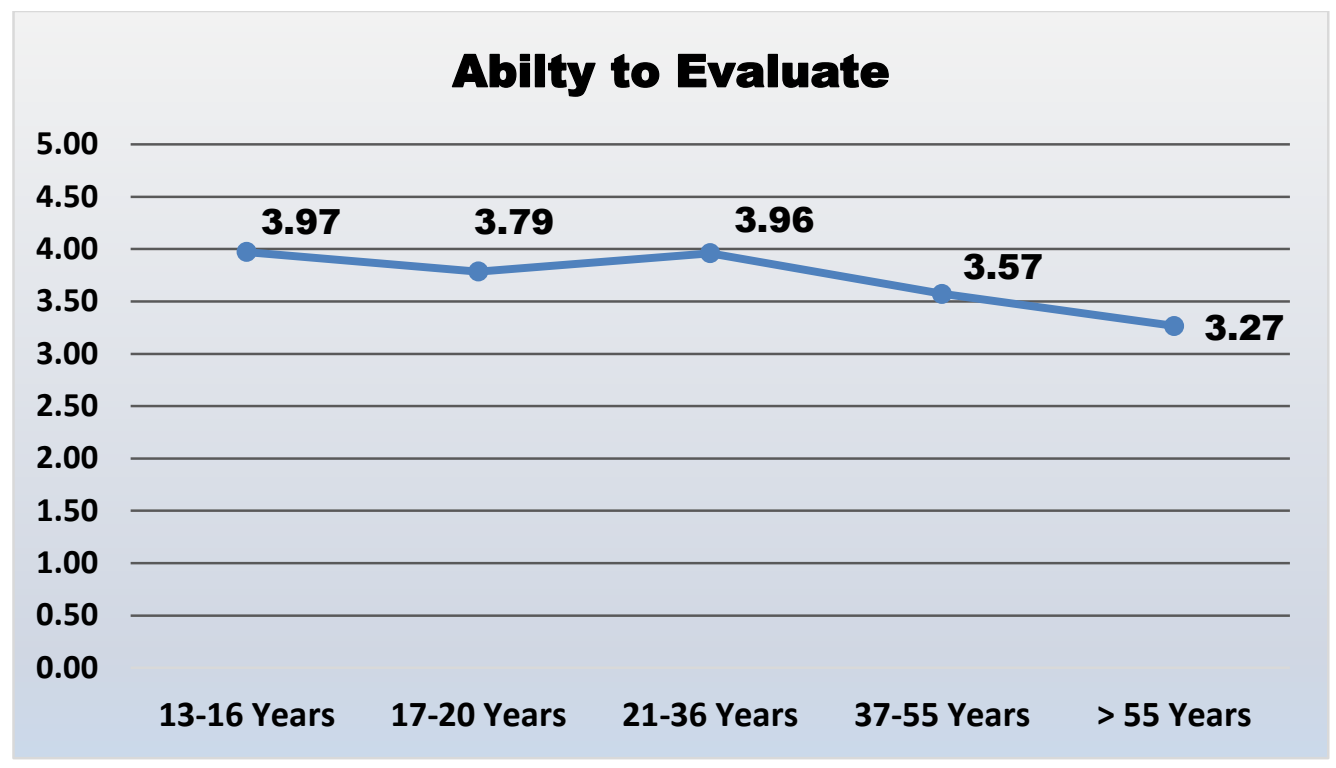

Figure 11. Ability to Evaluate

After verifying, the ability to evaluate becomes the next important digital literacy component. This type of ability is the final part of the decision-making of every digital media user when obtaining information. This ability specifically invites digital media users can determine reliable sources of information through various sources and assess the quality of information.

If we look at the conditions in Medan City, all age groups involved in the study are at a sufficient level. Only the 13-16 years and 21-36 years age groups scored close to the high level.

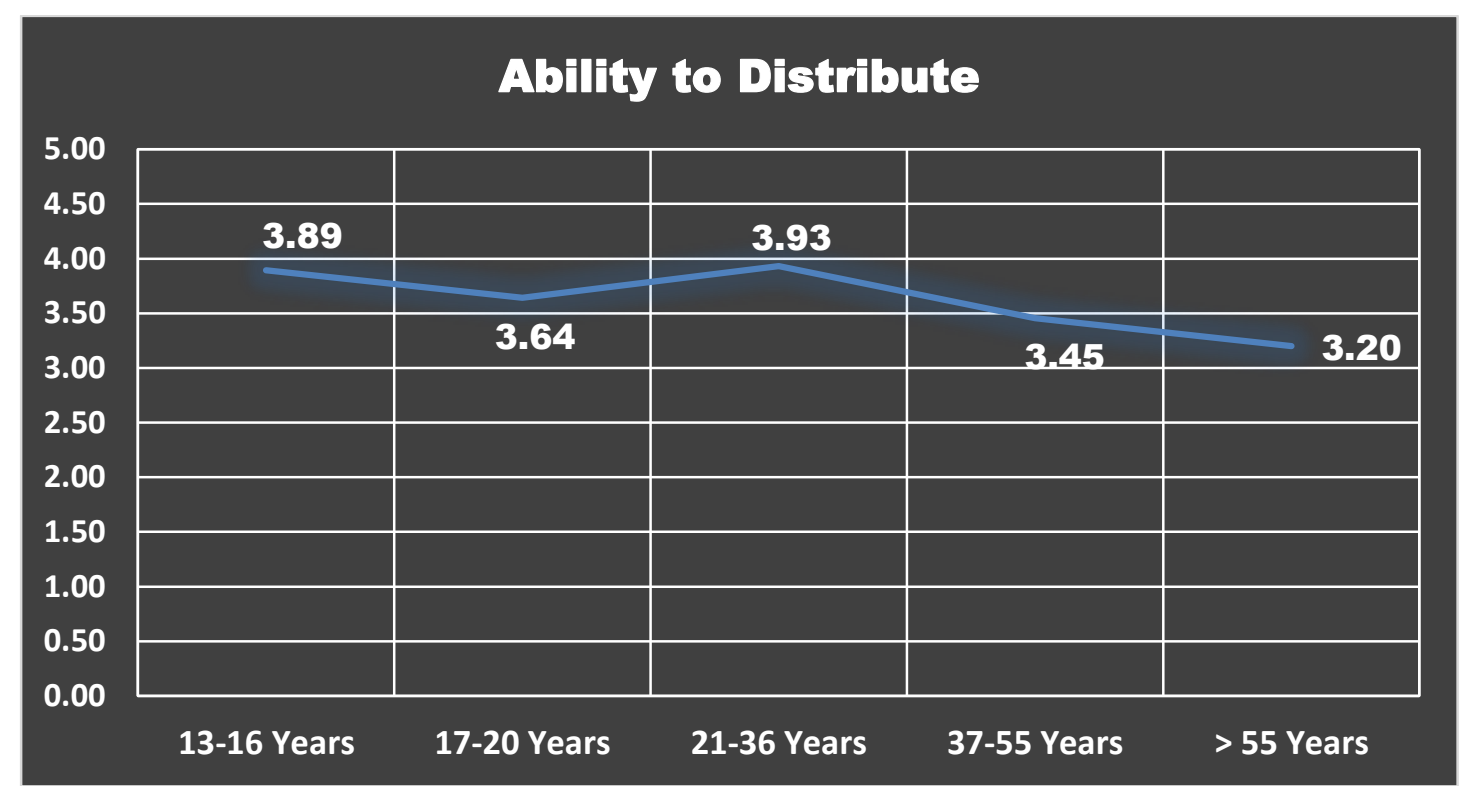

Table 12. Ability to Distribute

The ability to distribute digital literacy aspects in Medan City is in a sufficient category. The ability to distribute itself looks at how media users disseminate information according to the target and nature of a message as well as determine the suitability of the message with the media application. 
Ability to Produce

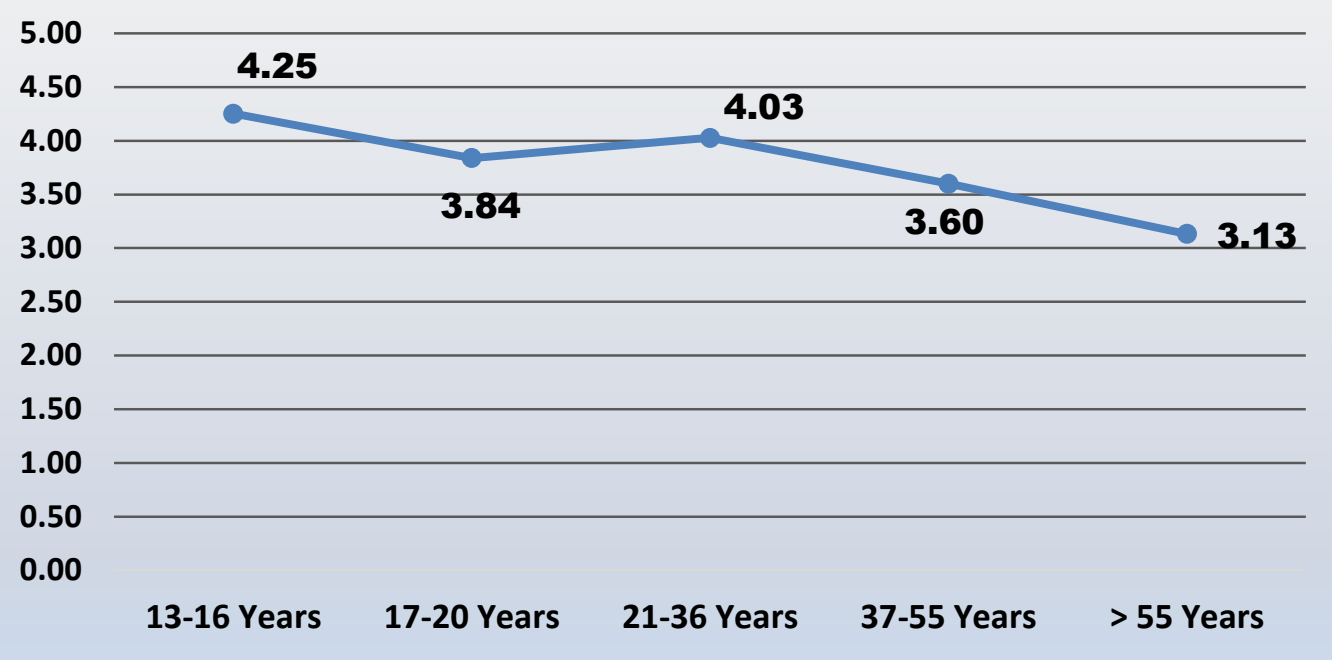

Figure 13. Ability to Produce

If we look in detail at the components in the ability to produce, this ability becomes one of the basic abilities when using digital devices. This ability assesses how a user of digital devices makes messages in written form, photos/images, and videos. However, in the findings in Medan City, only the age group of 13-16 years and 21-36 years were in the high category of assessment level. Meanwhile, the other three age groups have a sufficient score on this ability.

\section{Ability to Participate}

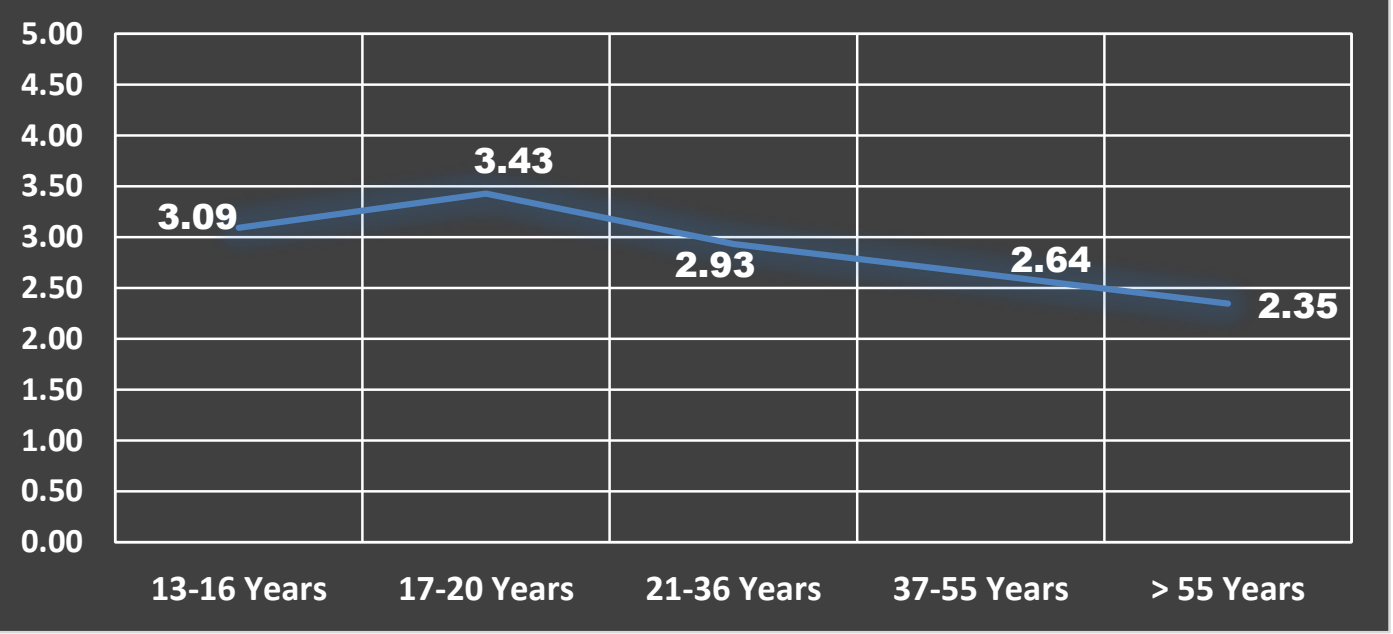

Figure 14. Ability to Participate

The ability to participate focuses on how digital media users are active in groups on social media. This capability will measure how involved digital media users are in online communities and their contribution to the group. However, it seems that the majority of people in Medan City are low to participate in online groups, especially for the age group 21-36 years, 37-55 years, and over 55 years. However, only the age groups of 13-16 years and 17-20 years were in the sufficient category on involvement in online groups. 
The ability to participate focuses on how digital media users are active in groups on social media. This capability will measure how involved digital media users are in online communities and their contribution to the group. However, it seems that the majority of people in Medan City are low to participate in online groups, especially for the age group 21-36 years, 37-55 years, and over 55 years. However, only the age groups of 13-16 years and 17-20 years were in the sufficient category on involvement in online groups.

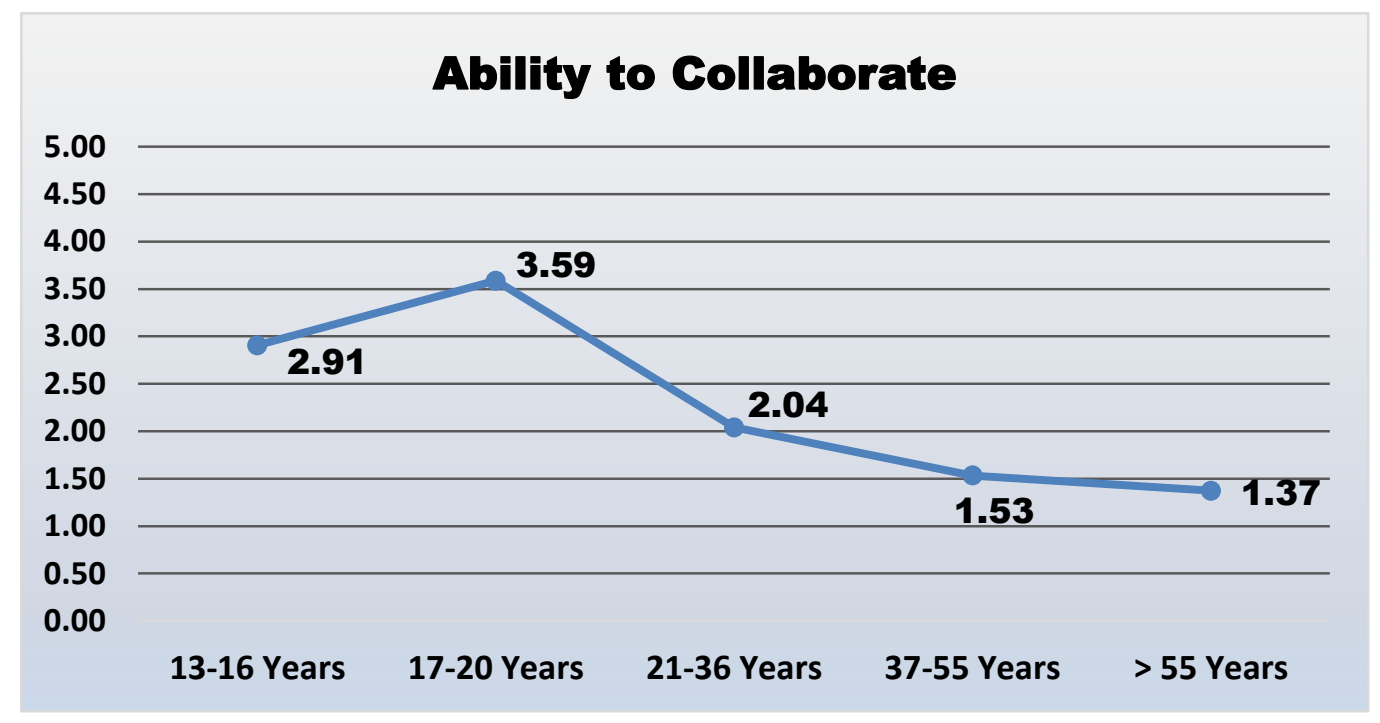

Figure 15. Ability to Collaborate

The ability to collaborate seems to be the ability with the lowest findings from Japelidi's research in Medan City. Specifically, the age group of 37-55 years and above 55 years have the very low category in this ability. Meanwhile, the age groups of 13-16 years and 21-36 years have a low level. Meanwhile, the age of 17-20 years has sufficient level in realizing this ability.

The ability to collaborate contextually wants to see how interaction and communication are built between digital media users with others in an online group. This ability wants to identify how the intensity of digital media users creates an online community. This ability also measures how digital media users can manage groups and the topics that have been delivered in the group.

One of the findings of research in Medan City shows that most people in the heavy user category spend 4-7 hours consuming digital media a day. In addition, the ability of all age groups to access digital media is above sufficient level, even three age categories of which have high access capabilities. It shows that technological developments have a very high appeal and implications, not only for the young age group but also for the elderly.

Judging from the Media Dependency Theory, the condition of internet access in the city of Medan, social changes that occur so quickly have resulted in people relying more on the media to get information (Littlejohn \& Foss, 2009, p. 812). The media production system operates in an ecosystem that has a dependent relationship with other social systems. These relationships not only influence media behavior but also form relationships that individuals as users can develop with the media (Ball-Rokeach, 2010).

The findings in this study indicate that the level of digital literacy competence between 5 age categories, consisting of ages 13-16 years, 17-20 years, 21-36 years, 37- 
55 years, and above 55 years, has different levels of ability. The difference in characteristics between generations is one of the causes of the inequality in digital technology usage. Although, it is not a dominant factor in influencing the digital literacy competence of each age group.

The age group of 13-16 years in Medan City became the initial age group that became respondents in the study. Research in Medan City shows that the age group of 13-16 years has a potent ability to master digital literacy competencies compared to all other age groups. The age group included in Generation $\mathrm{Z}$ are digital natives born at the same time as the development of digital technology. This age group is very familiar with digital technology from an early age. This age group tends to explore and create different content, as in early teens who are still in the stage of self-discovery (Mönks et al., 2014).

Furthermore, the age group of 17-20 years is still classified as Generation Z, who are familiar with digital technology. However, a stark difference in digital literacy competence was discovered between 17-20 years and 13-16 years. Meanwhile, they tend to have relatively minimal competence compared to the age of 13-16 years. Similarly, compared to the age group of 21-36 years, Generation Y (Millennials) are in an older age group than them. It shows that age is not the only factor that affects a person's digital literacy ability. However, there are knowledge gaps in the use of digital media, usage motives, and internet consumption time can be other parameters. The findings in this study emphasize that the 17-20 years age group spends more time focusing on strengthening relationships with peers (Mönks et al., 2014).

The age group of 21-36 years, which is dominated by the Millennial Generation, has digital literacy skills which are quite capable of facing digitalization. It is in line with the characteristics of the millennial generation that often access information development through credible institutions or media (Purawinangun \& Yusuf, 2020). So, it can be said that they can prevent the spread of hoaxes.

The majority of 37-55 years can classify into generation X. Digital literacy competence in this age group tends to have lower results than other age groups. It can not dispart from the characteristics of 37-55 years, most of whom are digital migrants. It is then continued with the finding that Generation X's knowledge and understanding of the use of technology are still relatively minimal (Fitri \& Prasetyawan, 2020).

Finally, the age group above 55 years is the age group that has the lowest digital literacy competence in Medan City. Most of them fall into the Baby Boomer category and classify as digital migrants, same as those aged 37-55 years. They make more efforts to adapt to various developments in information and communication technology increasingly (Venter, 2017). This situation was getting stronger by research conducted by (Schneider et al., 2018) that shows the majority of the Baby Boomer Generation have problems how to use technology to work, play, and learn, as did the Millennial Generation. It shows that Baby Boomers can classify as a group that can control the use of digital media, but not with their ability to counter the acceptance of fake news. When it comes to the digital literacy competence of the Baby Boomer generation in Medan City, they have the potential to become disseminators of misinformation content on social media platforms.

The literacy theory emphasized that all age groups acquire a basic understanding, which is applied as a social practice that reconfigures the traditional view of literacy education. The digital literacy pedagogy designed by Japelidi, as with the literacy theory mentioned by Joyce \& Feez (2016, p. 83), has succeeded in creating a parameter of 
knowledge and skills in controlling text, language, practical abilities, especially in the context of digital media. The discussion of each age in digital literacy skills shows an image of how digital literacy skills in Medan City based on age have gaps between generations.

\section{Conclusion}

Research conducted by Japelidi in Medan City in 2019 obtained several new findings in digital literacy competence. The finding shows an imbalance between the age group, between the younger generation represented by Generation $\mathrm{Z}$ and Millennial Generation, and those who are the older group, which comes from the age group of Generation $\mathrm{X}$ and Baby Boomers. This inequality is not only based on age differences alone but also differences in culture and use of technology in each era. The process of transitioning from technological developments to being all-digital, of course, forces every age group to be able to adapt to technological advances. However, most of the age group of 37-55 years and above 55 years cannot fully face and interpret digitalization. This condition certainly can impact the lack of understanding of digital literacy skills by this age group.

\section{Acknowledgements}

The authors would like to express the deepest gratitude to all Japelidi colleagues, especially to Novi Kurnia as Japelidi National Coordinator and Ni Made Ras Amanda Gelgel as Japelidi National Research Coordinator 2019.

\section{References}

Antara. (2018, January 31). 12 Provinsi Rawan Penyebaran Hoax. Media Indonesia. https://mediaindonesia.com/politik-dan-hukum/143254/12-provinsi-rawanpenyebaran-hoax.

Ariyanti, D. S. (2019, May 16). Survei: 75\% Penduduk Sumatra Utara Terhubung Internet. Bisnis.Com. https://sumatra.bisnis.com/read/20190516/533/923423/survei-75-penduduksumatra-utara-terhubung-internet

Ball-Rokeach, S. J. (2010). Media System Dependency Theory. In The International Encyclopedia of Communication. John Wiley \& Sons, Ltd. https://doi.org/10.1002/9781405186407.wbiecm051

BPS-Statistics Indonesia. (2019a). Statistics of Socio Culture 2018. https://www.bps.go.id/publication/2019/07/05/153a8fecadb642f5c4cf32e5/statisti k-sosial-budaya-2018.html

BPS-Statistics Indonesia. (2019b). Statistics of Indonesia Communications 2018. https://www.bps.go.id/publication/2019/12/02/6799f23db22e9bdcf52c8e03/statisti k-telekomunikasi-indonesia-2018.html

DailySocial.id. (2018). Hoax Distribution Through Digital Platforms in Indonesia 2018. https://dailysocial.id/research/hoax-distribution-through-digital-platforms-inindonesia-2018

de Joyce, H. S., \& Feez, S. (2016). Exploring Literacies (1st ed.). Palgrave Macmillan UK. https://doi.org/10.1057/9781137319036

Fitri, R. N., \& Prasetyawan, Y. Y. (2020). Literasi informasi generasi x, y, dan z dalam penyusunan karya tulis ilmiah Universitas Diponegoro. Jurnal Kajian Informasi \& Perpustakaan, 8(1), 21-34. https://doi.org/10.24198/jkip.v8i1.23233 
Gelgel, N. M. R. A., Rahmiaji, L. R., \& Limilia, P. (2021). Pemetaan Kompetensi Literasi Digital Masyarakat Indonesia 2019 (1st ed.). Pustaka Larasan.

Haryanto, I. (2014). Jurnalisme Era Digital: Tantangan Industri Media Abad 21 (M. Vergina, Ed.; 1st ed.). PT Kompas Media Nusantara.

Hasanuddin. (2021, May 13). Internet adalah Candu: Fenomena Pengguna Internet Indonesia. Alvara Strategic. https://alvara-strategic.com/internet-adalah-candufenomena-pengguna-internet-indonesia/

Hasfi, N. H., Gono, J. N., \& Rakhmad, W. N. (2020). Internet Access and the Potential in Facilitating Online Political Communication of Disabled. Jurnal ASPIKOM, 5(1), 36-49. https://doi.org/10.24329/aspikom.v5i1.468

Herlina, D. (2019). Literasi Media: Teori dan Fasilitasi (1st ed.). Remaja Rosdakarya.

Indonesian Internet Service Providers Association. (2018). Laporan Survei Penetrasi \& Profil Perilaku Pengguna Internet Indonesia 2018. https://apjii.or.id/survei2018

Kementerian Komunikasi dan Informatika, \& Katadata Insight Center. (2020). STATUS LITERASI DIGITAL INDONESIA 2020 (Hasil Survei di 34 Provinsi). https://literasidigital.id/sdm_downloads/status-literasi-digital-indonesia-2020hasil-survei-di-34-provinsi/

Khan, F., \& Vuopala, E. (2019). Digital Competence Assessment Across Generations. International Journal of Digital Literacy and Digital Competence, 10(2), 15-28. https://doi.org/10.4018/IJDLDC.2019040102

Kholisoh, N. (2018). Pengaruh Terpaan Informasi Vlog di Media terhadap Sikap Guru dan Dampaknya terhadap Persepsi Siswa. Jurnal ASPIKOM, 3(5), 1002-1014. https://doi.org/10.24329/aspikom.v3i5.380

Kurnia, N., \& Astuti, S. I. (2017). PETA GERAKAN LITERASI DIGITAL DI INDONESIA: STUDI TENTANG PELAKU, RAGAM KEGIATAN, KELOMPOK SASARAN DAN MITRA YANG DILAKUKAN OLEH $\begin{array}{llll}\text { JAPELIDI. INFORMASI, } & \text { 47(2), }\end{array}$ https://doi.org/10.21831/informasi.v47i2.16079

Kurnia, N., Monggilo, Z. M. Z., \& Adiputra, W. M. (2018). Yuk, Tanggap \& Bijak Berbagi Informasi Bencana Alam Melalui Aplikasi Chat (1st ed.). Program Studi Magister Ilmu Komunikasi, Universitas Gadjah Mada. https://literasidigital.id/books/yuk-tanggap-bijak-berbagi-informasi-bencana-alammelalui-aplikasi-chat/

Kusumastuti, F., Kurnia, N., \& Astuti, S. I. (2021). Pengantar Etis Bermedia Digital. In F. Kusumastuti \& S. I. Astuti (Eds.), Modul Etis Bermedia Digital (pp. 1-17). Kementerian Komunikasi dan Informatika. https://literasidigital.id/books/moduletis-bermedia-digital/

Lin, T.-B., Li, J.-Y., Deng, F., \& Lee, L. (2013). International Forum of Educational Technology \& Society Understanding New Media Literacy: An Explorative Theoretical Framework. Source: Journal of Educational Technology \& Society, 16(4), 160-170. https://doi.org/10.2307/jeductechsoci.16.4.160

Littlejohn, S., \& Foss, K. (2009). Encyclopedia of Communication Theory. SAGE Publications, Inc. https://doi.org/10.4135/9781412959384

Loisa, R., Susanto, E. H., Junaidi, A., \& Loekman, F. (2019). MEDIA SIBER, APARAT, DAN PEMBERITAAN KEBERAGAMAN. Jurnal ASPIKOM, 3(6), 1243-1253. https://doi.org/10.24329/aspikom.v3i6.434

Mansur, S., Saragih, N., Ritonga, R., \& Damayanti, N. (2021). Fake News on Social Media and Adolescent's Cognition. Jurnal ASPIKOM, 6(1), 29-41. 
https://doi.org/10.24329/aspikom.v6i1.827

Monggilo, Z. M. Z., Kurnia, N., \& Astuti, S. I. (2021). Literasi Digital dan Kecakapan Digital. In Z. M. Z. Monggilo \& N. Kurnia (Eds.), Modul Cakap Bermedia Digital (1st ed., pp. 1-19). Kementerian Komunikasi dan Informatika. https://literasidigital.id/books/modul-cakap-bermedia-digital/

Mönks, F. J., Knoers, A. M. P., \& Haditono, S. R. (2014). Psikologi Perkembangan: Pengantar dalam Berbagai Bagiannya (17th ed.). Gadjah Mada University Press.

Musiin, \& Indrajit, R. E. (2020). Literasi Digital Nusantara, Meningkatkan Daya Saing Generasi Muda Melalui Literasi (1st ed.). ANDI Publisher.

Nurlatifah, M. (2019). THE FIGHT AGAINST HOAX: AN EXPLORATIVE STUDY TOWARDS ANTI-HOAX MOVEMENTS IN INDONESIA. Jurnal Komunikasi: Ikatan Sarjana Komunikasi Indonesia, 4(1), 46-54. https://doi.org/10.25008/jkiski.v4i1.227

Pradsmadji, S. I., \& Irwansyah, I. (2020). Media Convergence in the Platform of Videoon-Demand: Opportunities, Challenges, and Audience Behaviour. Jurnal ASPIKOM, 5(1), 115-128. https://doi.org/10.24329/aspikom.v5i1.491

Purawinangun, I. A., \& Yusuf, M. (2020). GERAKAN LITERASI GENERASI MILENIAL MELALUI MEDIA SOSIAL. Lingua Rima: Jurnal Pendidikan Bahasa Dan Sastra Indonesia, 9(1), 67-75. https://doi.org/10.31000/lgrm.v9i1.2401

Rianto, P. (2016). MEDIA BARU, VISI KHALAYAK AKTIF DAN URGENSI LITERASI MEDIA. Jurnal Komunikasi Ikatan Sarjana Komunikasi Indonesia, 1(2), 90-96. https://doi.org/10.25008/jkiski.v1i2.54

Rosemary, R., Syam, H. M., Anisah, N., Yanuar, D., \& Putra, H. S. (2021). Acehnese People's Information Seeking Behavior about COVID-19. Jurnal Komunikasi Ikatan Sarjana Komunikasi Indonesia, 6(1), 161-170. https://doi.org/10.25008/jkiski.v6i1.482

Schneider, B. C., Schröder, J., Berger, T., Hohagen, F., Meyer, B., Späth, C., Greiner, W., Hautzinger, M., Lutz, W., Rose, M., Vettorazzi, E., Moritz, S., \& Klein, J. P. (2018). Bridging the "digital divide": A comparison of use and effectiveness of an online intervention for depression between Baby Boomers and Millennials. Journal of Affective Disorders, 236, 243-251. https://doi.org/10.1016/j.jad.2018.04.101

Sugiyono. (2019). Metode Penelitian Kuantitatif, Kualitatif, dan R\&D (Sutopo, Ed.; 2nd ed.). Alfabeta.

Sugiyono, \& Susanto, A. (2017). Cara Mudah Belajar SPSS dan LISREL : Teori dan Aplikasi untuk Analisis Data Penelitian (1st ed.). Alfabeta.

Sulthan, M., \& Istiyanto, S. B. (2019). MODEL LITERASI MEDIA SOSIAL BAGI MAHASISWA. Jurnal ASPIKOM, 3(6), 1076-1092. https://doi.org/10.24329/aspikom.v3i6.280

Suryatmoko, \& Saputro, K. A. (2015). Literasi Media dan Pendidikan Rakyat. In Y. Arief \& W. P. Utomo (Eds.), Orde Media: Kajian Televisi dan Media di Indonesia Pasca-Orde Baru (1st ed., pp. 270-275). INSISTPress \& Remotivi.

Susilo, M. E., Yustitia, S., \& Afifi, S. (2020). Intergeneration Comparison of the Spread Pattern of Hoax. Jurnal ASPIKOM, 5(1), 50-62. https://doi.org/10.24329/aspikom.v5i1.533

Venter, E. (2017). Bridging the communication gap between Generation Y and the Baby Boomer generation. International Journal of Adolescence and Youth, 22(4), 
497-507. https://doi.org/10.1080/02673843.2016.1267022

We are Social, \& Hootsuite. (2019). Digital 2019: Indonesia. https://datareportal.com/reports/digital-2019-indonesia

Widiastuti, T., \& Ritonga, R. (2020). Ethnomethodology Study of Digitalized Social Communication Apprehension in Basmala Youth Community Members. Jurnal Komunikasi Ikatan Sarjana Komunikasi Indonesia, 5(1), 42-51. https://doi.org/10.25008/jkiski.v5i1.362 